Arq. Bras. Med. Vet. Zootec., v.59, n.1, p.140-144, 2007

\title{
Temporomandibular joint ankylosis and salivary mucocele in a cat: case report
}

\author{
[Anquilose da articulação temporomandibular e mucocele em um gato: relato de caso] \\ S.C. Rahal, M.J. Mamprim, E.H. Caporali, R.B. Ciani \\ Faculdade de Medicina Veterinária e Zootecnia - UNESP \\ Distrito de Rubião Júnior s/n \\ 18618000 - Botucatu, SP
}

\begin{abstract}
An approximately 1.5-year-old, not neutered mixed breed cat was referred for evaluation of inability to open its mouth, and soft tissue swelling around the intermandibular region. Both signs were present since the cat was adopted, 1 year before presentation. The cause of the signs was not determined prior to referral. Based on the physical and radiographic examinations, left temporomandibular joint ankylosis and salivary mucocele were diagnosed. The lateral aspect of the condyloid process of the left mandible was removed and the salivary mucocele was treated by right mandibular and sublingual gland resection and drainage of the mucocele. After surgery, the cat showed good functional use of the mandible without discomfort.
\end{abstract}

Keywords: cat, surgery, mandible

\section{RESUMO}

Relata-se o caso de um gato de aproximadamente um ano e meio de idade, macho, não castrado, que foi encaminhado por apresentar incapacidade de abrir a boca e aumento de volume flutuante na região intermandibular. As lesões estavam presentes há um ano, desde quando o gato foi encontrado e adotado. A causa não foi determinada. Baseado nos exames físicos e radiográficos diagnosticou-se anquilose da articulação temporomandibular esquerda e mucocele salivar. O aspecto lateral do processo condilar da mandibula esquerda foi removido, e a mucocele foi tratada por ressecção das glândulas salivares mandibular e sublingual direita e por drenagem da mucocele. Após a cirurgia, o gato mostrou bom uso funcional da mandibula, sem sinais de desconforto.

Palavras-chave: gato, cirurgia, mandibula

\section{INTRODUCTION}

Temporomandibular ankylosis and salivary mucocele are not common in cats (Waldrom and Smith, 1991; Okumura et al., 1999). Temporomandibular ankylosis may be defined as consolidation or abnormal immobility of the joint, which can occur unilaterally or bilaterally (Lantz, 1985; Sullivan, 1989; Okumura et al., 1999). True ankylosis involves intracapsular structures and false ankylosis is caused by extracapsular lesions (Lantz, 1985; Van EE and Pechman, 1987; Sullivan, 1989). In general, ankylosis is associated with trauma, inflammation, tumors, and developmental conditions (Lantz, 1985; Van EE and Pechman, 1987; Sullivan, 1989; Okumura et al., 1999). In cats, most reports are associated with trauma (Van EE and Pechman, 1987; Sullivan, 1989; Okumura et al., 1999). Conservative treatment using corticosteroids and forced stretching of the jaw is generally ineffective (Sullivan, 1989), and may result in relapse one month after the procedure (Meomartino et al., 1999). The best results are obtained with procedures such as condylectomy, partial zygomatic arch resection, coronoidectomy and resection of proliferative bone (Van EE and Pechman, 1987; Sullivan,

Recebido em 10 de fevereiro de 2005

Aceito em 2 de outubro de 2006

E-mail: sheilacr@fmvz.unesp.br 
1989; Meomartino et al.; 1999; Okumura et al., 1999).

Salivary mucocele consists of an accumulation of saliva in the subcutaneous tissue adjacent to a salivary gland or duct (Brown, 1989; Dunning, 2002). In general, if the sublingual gland or its duct is involved, the saliva may be collected in the subcutaneous tissues of the intermandibular or cervical areas (cervical mucocele), sublingual tissues (ranula), or pharyngeal wall (pharyngeal mucocele) (Brown, 1989; Waldron and Smith, 1991). In most cases, the cause of salivary mucoceles may not be determined, but predisposing factors include foreign body penetration, facial trauma or surgery (Brown, 1989; Dunning, 2002). Resection of the affected gland is the definitive treatment to salivary mucocele (Dunning, 2002).

\section{CASE DESCRIPTION}

An approximately 1.5-year-old, not neutered mixed breed cat weighing $3.7 \mathrm{~kg}$, was referred to the Veterinary Hospital for evaluation and management of inability to open its mouth, and soft tissue swelling around the intermandibular region. According to the owner, both signs were present since the cat was adopted, 1 year prior to presentation. The cat was exclusively fed with liquid diet and was unable to groom itself. Previous treatments using forced stretching of the jaw, corticosteroid therapy, and periodic drainage of the soft tissue swelling were unsuccessful.

Physical examination revealed malocclusion of the mouth with left deviation of the mandible. The mouth was maintained open at $3 \mathrm{~mm}$. There was moderate atrophy of the masseter musculature and a nonpainful fluctuant swelling mainly located in the right side of the intermandibular region. The mandible was deviated $3 \mathrm{~mm}$ to the left and the mouth could not be opened or closed (Fig. 1). The malocclusion resulted in the lower canine tooth impinging on the palate between the upper canine and upper third incisor teeth. The space between the lower canine teeth was diminished and could only accommodate the presence of two incisor teeth.

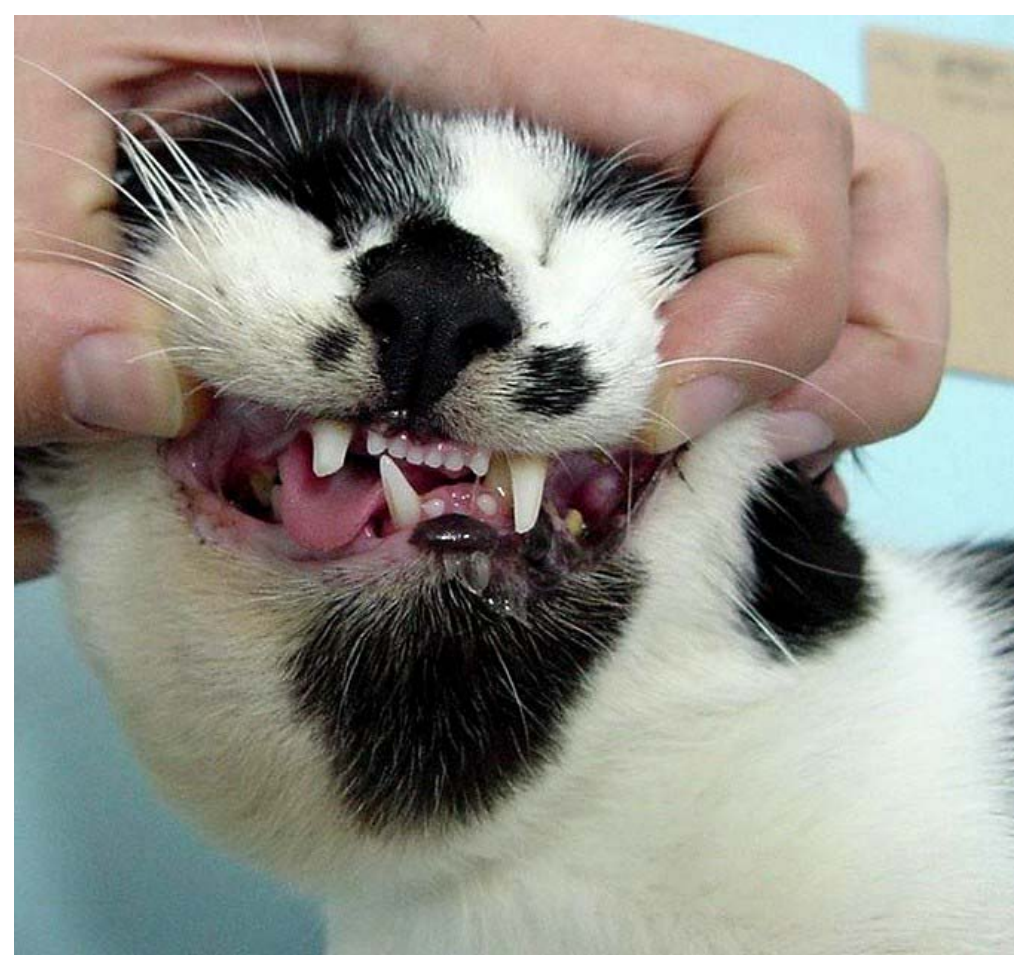

Figure 1. Preoperative view of the cat. Observe malocclusion of the mouth, and swelling located in the intermandibular region. The mandible was deviated $3 \mathrm{~mm}$ to the left, and the mouth could not be opened or closed. 
Moderate dental calculus and halitosis were also present. Aspiration of the intermandibular swelling revealed the presence of a yellowish mucoid fluid. Radiographs of the head showed rostrodorsal luxation of the left temporomandibular joint and the right joint appeared normal (Fig. 2). A submandibular soft tissue opacity was also evident (Fig. 2). Based on the physical and radiographic findings, temporomandibular joint ankylosis and cervical salivary mucocele were diagnosed. The owners of the cat opted for surgical management of the diagnosed condition.
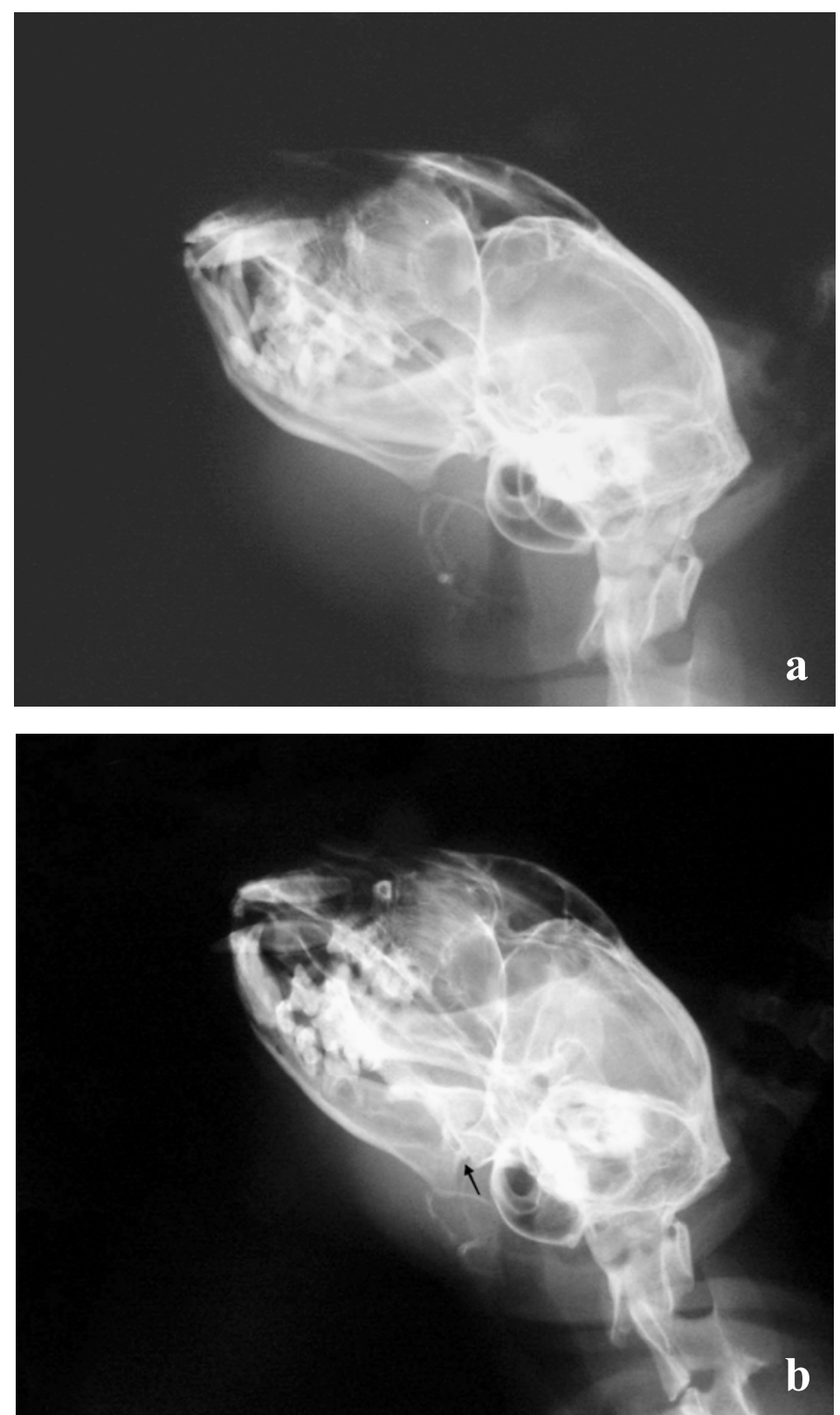

Figure 2. Right lateral oblique and (a) left lateral oblique (b) radiographic views of the head of a mixed breed cat examined due to the inability to open its mouth. Observe the right temporomandibular joint apparently normal (a), and luxation of the left temporomandibular joint (arrow) (b) and soft tissue opacity located in the submandibular area $(a, b)$. 
After premedication with acepromazine $(0.05 \mathrm{mg} / \mathrm{kg}$ IM) and morphine $(0.3 \mathrm{mg} / \mathrm{kg} \mathrm{IM})$ anaesthesia was induced and maintained with tiletamine/zolazepam combination $(15 \mathrm{mg} / \mathrm{kg}$ IM). An incision in the masseter muscle ventrally and caudally oriented in relation to the end of the zygomatic arc was made and the area of the left temporomandibular joint was approached. A condylectomy was performed by removal of the lateral aspect of the condyloid process of the left hemimandible using roungers, and the mouth was forcibly opened to break down remnant adhesions. A right mandibular and sublingual salivary gland resection was, then, carried out. The mucocele was drained via a stab incision made directly over the swelling. Cephalexin $(30 \mathrm{mg} / \mathrm{kg}, \mathrm{PO}, \mathrm{q} 12 \mathrm{~h}$, for $10 \mathrm{~d})$ and tramadol hydrochloride $(2 \mathrm{mg} / \mathrm{kg}, \mathrm{PO}, \mathrm{q} 8 \mathrm{~h}$, for $5 \mathrm{~d})$ were administered. Following the above procedure, the malocclusion was not markedly improved, however, the oral cavity could be opened to a larger degree than it was preoperatively. Jaw movement did not reach the normal range (Fig. 3).

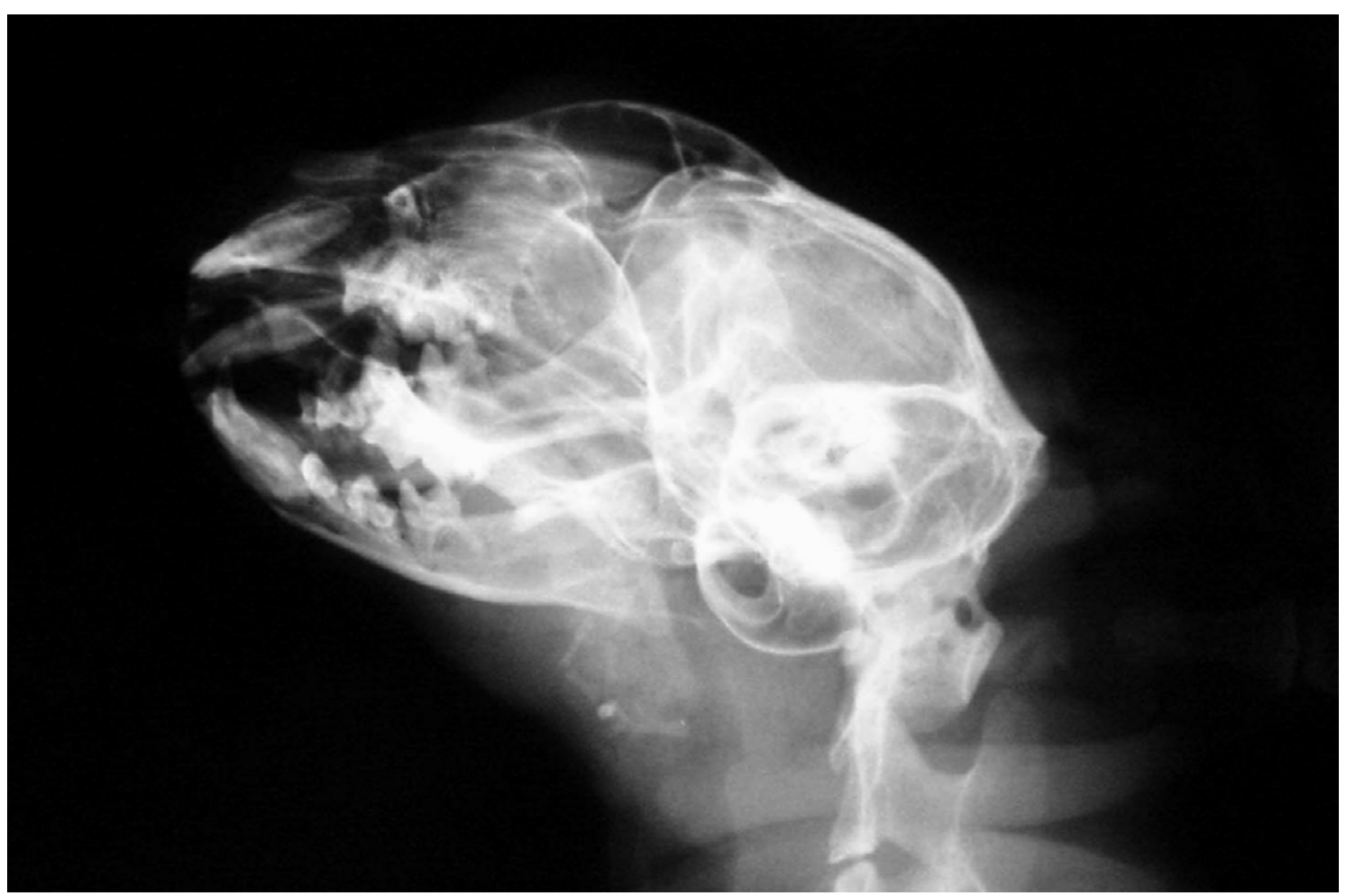

Figure 3. Left lateral oblique radiograph of the head immediately after surgery showing the opened mouth.

A few days after surgery, the cat was able to clean itself and to eat softened canned food, without discomfort. Two months later, the cat died after being hit by a car. Post-mortem examination of the head confirmed normal right temporomandibular joint and absence of the lateral aspect of the condyloid process of the left hemimandible which was surgically removed. In addition, an irregular bony proliferation on the external surface of left mandibular ramus and on the medial aspect of zygomatic bone was observed. The length of left mandible body was also smaller than the right.

\section{DISCUSSION}

In general, chronic ankylosis makes the detection of the primary lesion difficult (Meomartino et al., 1999). It was hypothesized that the cat of this report, initially, suffered a trauma resulting in temporomandibular luxation that was responsible for the malocclusion. Because the cat was not properly treated, false temporomandibular ankylosis developed. Traumatic episodes reported to have resulted in ankylosis include luxation of the condylar process and fractures of zygomatic arc, condyloid process, retroarticular 
process, and coronoid process (Van EE and Pechman, 1987; Lantz, 1991; Meomartino et al., 1999). The length of left mandible body was smaller than the right, probably, because the ankylosis developed during skeletal growth. According to Lantz (1991), little or no facial deformity is observed when the ankylosis develops in adults.

Because conservative treatment is always unsuccessful (Sullivan, 1989; Meomartino et al., 1999), surgical treatment is considered the best option. The surgical procedure should restore jaw motion and avoid the recurrence by removing the ankylosed tissue and, if necessary, the mandibular condyle (Sullivan, 1989; Lantz, 1991; Okumura et al., 1999). Some complications may occur after excision arthroplasty of temporomandibular joint, especially in bilateral cases. In general, however, acceptable cosmetic and functional results have been observed in experimental and clinical cases reported in dogs and cats (Lantz et al., 1982; Tomlinson and Presnell, 1983; Meomartino et al., 1999). In this case, unilateral removal of the lateral aspect of the condyloid process was effective in reestablishing normal function. This procedure differs of the most frequently performed such as total condylectomy including or not partial zygomatic arch resection (Sullivan, 1989; Meomartino et al., 1999; Okumura et al., 1999). Unfortunately, it was not possible to know the longterm results of the technique used in this case, since the animal died during the postoperative period. In spite of that, the owner reported that the cat showed good functional use of the mandible. Although the technique improved the ability of the cat to open its mouth, the malocclusion could not be improved. Other authors observed the same finding (Lantz, 1985; Sullivan, 1989; Okumura et al., 1999). The extraction of the left lower canine tooth and realignment of the mandibular symphysis (Buchet and Boudrieu, 1999) could be used to correct the malocclusion in this case, but the owner declined these procedures.

In this case the predisposing factor to the development of salivary mucocele may be associated to trauma as well (Brown, 1989; Dunning, 2002). Although the ankylosis was located in the left temporomandibular joint, the mucocele was associated with right sublingual salivary gland and its duct. Since the mucocele has no secretory lining, treatment with aspiration or drainage of the mucocele alone is not recommended because of recurrence in most cases (Waldrom and Smith, 1991; Dunning, 2002). Although most of the mucocele arises from the sublingual gland and its duct system, the mandibular salivary gland and its duct are excised together because of the close anatomic relationship (Dunning, 2002).

\section{REFERENCES}

BROWN, N.O. Salivary gland diseases. Prob. Vet. Med., v.1, p.281-294, 1989.

BUCHET, M.; BOUDRIEU, R.J. Correction of malocclusion secondary to maxillary impaction fractures using a mandibular symphyseal realignment in eight cats. J. Am. Anim. Hosp. Assoc., v.35, p.68-76, 1999.

DUNNING, D. Oral cavity. In: SLATTER, D.H. (Ed.). Textbook of small animal surgery. 3.ed. Phildelphia: Saunders, 2002. chap 39, p.553-572.

LANTZ, G.C. Surgical correction of unusual temporomandibular joint conditions, Compend. Contin. Educ. Pract. Vet., v.13, p.1570-1576, 1991.

LANTZ, G.C. Temporomandibular joint ankylosis: surgical correction of three cases. J. Am. Anim. Hosp. Assoc., v.21, p.173-177, 1985.

LANTZ, G.C.; CANTWELL, H.D.; Van VLEET, J.F. et al. Unilateral mandibular condylectomy: experimental and clinical results. J. Am. Anim. Hosp. Assoc., v.18, p.883-890, 1982.

MEOMARTINO, L.; FATONE, G.; BRUNETTI, A. et al. Temporomandibular ankylosis in the cat: a review of seven cases. Small Anim. Pract., v.40, p.7$10,1999$.

OKUMURA, M.; KADOSAWA, T.; FUJINAGA, T. Surgical correction of temporomandibular joint ankylosis in two cats. Aust. Vet. J., v.77, p.24-27, 1999.

SULLIVAN, M. Temporomandibular ankylosis in the cat. J. Small Anim. Pract., v.30, p.401-405, 1989.

TOMLINSON, J.; PRESNELL, K.R. Mandibular condylectomy. Vet. Surg., v.12, p.148-154, 1983.

VAN EE, R.T.; PECHMAN, R.D. False ankylosis of the temporomandibular joint in a cat. J. Am. Vet. Med. Assoc., v.191, p.979-980, 1987.

WALDRON, D.R.; SMITH, M.M. Salivary mucocele. Prob. Vet. Med., v.3, p.270-276, 1991. 